\title{
FÜGGELÉK
}

1.

\section{KOVÁCS ISTVÁN}

\section{AZ ERDÉLYI MÚZEUM-EGYLET MEGALAKULÁSÁNAK 50 ÉVES JUBILEUMA ÉS JUBILÁRIS PLAKETTJE}

Ha a plakett révén, e folyóirat hasábjain, hosszasabban foglalkozunk az Erdélyi Múzeum-Egyesület megalakulásának történetével, szolgáljon indokul az, hogy az Egyesület kebelében született meg és azon növekedik ma is hazánk egyik nagyobb éremgyưjteménye, az Erdélyi Nemzeti Múzeum éremtára. Így válik az Egyesület jubileuma az éremtár ünnepévé, és így számíthat érdeklődésre az egyesületnek mint szülő intézménynek múltja e folyóirat olvasójánál is.

A múzeum gondolata nem ötven év előtt született meg Erdély területén. Ötven évvel ezelőtt megvalósittották az eszmét, de szükségérzete hamarább mutatkozott, kisarjadzása is jóval előbb megtörtént.

Az erdélyi részek mindig fontos kisugárzó területei voltak a nemzeti törekvéseknek. Nem egyedül rajta múlt, ha törekvéseit mindenben siker nem koronázta. Erdély, önálló fejedelmei alatt, nem egyszer sietett az anyaállam megtartására. A nemzeti nevelésben pedig éppen elöl járt magyar fejedelmi udvarával. A tanulni vágyó ifjak részére intézményileg biztosították fejedelmei a külföldi egyetemek látogatását, és ezek révén állandó szellemi összeköttetést tartottak fenn a múvelt nyugattal. A felvilágosodás, haladás magvait aztán itthon hintegették el a tudós férfiak, és szogalmas kezekkel ápolgatták a már hazai földből kinövő plántákat. Átalakítani azonban az egész társadalmat olyanná, amilyennek képe az ő lelkükben élt, csak hoszszas, százados munka árán sikerülhetett utódaiknak. Mikor azonban idáig jutottak, megváltoztak a politikai viszonyok is.

Bod Péter már elérkezettnek látta az időt arra is, hogy programot adjon arról, miképpen kell a nemzetet múvelni. Az általa tervezett Akadémia eszméje azonban, csakúgy mint kevéssel utóbb Batthyányi Ignác „Tudós társasága", megvalósítatlan maradt. 
Annál maradandóbb sikerrel tudtak irodalmi és nyelvmívelő társaságokat alakítani Arankáék és Döbrentei Gábor. De ezek mindvégig magánvállalkozások maradtak. Országos alapon való szervezésüket megakadályozta a pénzhiány, főleg azonban a kormány rosszakarata, amely midennek, ami nemzeti célt szolgált, Kain-ellensége volt. Ilyen fogadtatásban részesült a Főkormányszék részéről Bölöni Farkas Sándor tervezete is, amely egyenesen gyűjtemények, muzeális anyag segítségével kívánta a nemzet múvelődését előbbre vinni. Sikertelenül. Gondoskodtak róla, hogy törekvéseinek minél hamarább nyakát szegjék. A kormány magatartása intő jelül szolgálhatott a nemzetnek, melyet mind jobban áthatott annak a tudata, hogy egyesülni kell a közös cél érdekében, a haza, szabadság és művelődés felvirágoztatására. Minél inkább tört a nemzet ellen az ármány, annál féltékenyebben ragaszkodott intézményeihez, szokásaihoz, és annál nagyobb kegyelettel őrizte a múltak emlékét. A kegyeletes emlékezés megszentelte a tárgyi emlékeket is, amelyekben a nemzet elei dicső korának emlékeit s jövendő boldogságának zálogát látta.

Széltében alakultak kisebb-nagyobb magánkönyvtárak és gyüjtemények, melyek mindenütt lelki szükséget elégittettek ki. Csak egy lépés kellett ahhoz, hogy megszülessék a múzeum gondolata, mely országos alapon szervezve egyaránt szolgálhatja a nemzet müvelését, a múlt iránt érezett kegyeletet $\mathrm{s}$ a nemzeti összetartást.

Gróf Kemény József tette meg az első lépést a múzeumi eszme megvalósítása érdekében azzal, hogy gazdag könyvtárát egy létesítendő múzeum céljaira felajánlotta. Ajánlatának hatása alatt az 1842-diki erdélyi országgyűlés törvényjavaslatot dolgozott ki a létesítendő múzeum számára, de a szászok akadékoskodása miatt az országgyülés végéig a javaslatból nem lett törvény, azután pedig a kormány halogatása miatt nem lehetett többé napirendre tűzni. Az unió kimondását nyomon követte a szabadságharc. Ennek lezajlása után a nemzetre nehezedő elnyomatás kora jó sokáig nem volt alkalmas arra, hogy a múzeumi eszme felszínre kerüljön és nyilvánosan tárgyaltassék. De az utána való vágyakozás nem szünt meg, sőt határozottabb formában élt a nemzet során kesergő honfiak lelkében. Alighogy Ausztriát a külügyi helyzet alakulása elfoglalta s kezdett megfogyatkozni az abszolutizmus ereje, mindjárt ismét aktuálissá lett a múzeum kérdése. Erre a közvetlen alkalmat gróf Kemény Józsefnek 1855-ben bekövetkezett halála szolgáltatott. Kemény ti. végrendeletében is a felállítandó múzeum számára hagyta könyvtárát, de addig is, míg saját épületébe költözhetik, a Magyar Nemzeti Múzeum őrizetére bízta gyűjteményét.

Az erdélyiek azonban nem akarták kiengedni kezeik közül az Erdélyt érdeklő könyvekben és kéziratokban bővelkedő gyüjteményt, márcsak azért sem, mert félni lehetett attól, hogy a kormány a szebeni szász gyüjte- 
mény gyarapítására fordítja. Társadalmi úton indítottak tehát mozgalmat a Kolozsvárt felállítandó múzeum érdekében. Talán most sem koronázza siker a jó ügy lelkes felkarolását, ha gróf Mikó Imre, a gazdag és tekintélyes erdélyi fớr és államférfiú, nem veszi kezébe az ügyek vezetését. Gróf Mikó ezt megelőzőleg is melegen táplálta magánérintkezései és -levelezései során a muzeális gondolatot.

Alig hangzottak el most az első szavak a múzeum érdekében, 1856-ban a „Kolozsvári Közlöny” hasábjain rámutatott arra, hogy a Kemény-féle gyűjtemény elhelyezése a legsürgősebb feladat, s egyben ennek megoldásáról is gondoskodott olyanformán, hogy a múzeum céljaira odaadományozta Külső-Szén utcai 10 holdas kertjét a rajta épült kilencszobás villával egyetemben. Most már csak idő kérdése volt az Egyesület megalakulása. Az áldozatkészség önmagából merített erőt, kitartást ettől kezdve. Mikó felszólítására egész sereg pénzbeli segítséget és tárgyat ajánlanak a honfiak a múzeum céljaira. Közben Mikó egy szűkebb körü bizottsággal az alapszabályok kidolgozásán fáradozott, hogy előkészítse a megalakulást.

A kormány azonban most sem mulasztotta el kedvét szegni a pezsgésbe jött honfiúi lelkeknek. Az alapszabályokat ismételten visszaküldötte, és olyan módosításokat kívánt azon tenni, melyek minden nemzeti jelleget eleve letörültek volna az intézményről. Így meg a nemzetnek nem kellettek. Már-már ismételten belefáradt a nemzet sikertelen kísérletekbe és a kormány részéről megnyilatkozó huzavonába, mikor gróf Mikó szerét ejtette mégis olyan módosításoknak, melyek úgy fölfelé, mint lefelé kielégíthették a kedélyeket.

A végre megerősített alapszabályok leérkeztek, és 1859. november 23-án megalakulhatott az Erdélyi Múzeum-Egyesület, gróf Mikó Imre elnöklete alatt. „Szinte négy évi törekvés után a kezdetnek valahára a végén vagyunk." ĺgy kezdhette Mikó megnyitó beszédét a vezetése alatti küzdelmekre célozva. Majd így folytatta: „Legyen e nap nekünk ünnep, szándékaink és amit teszünk, legyenek Istentől megáldva." És valóban a nap, melyen a nemzet végre célját elérhette, ünnepnappá lett. Az alapítók szándékait, tetteit valóban Isten áldása kísérte.

Az Egyesület 50 év után is él és virágzik. Az ötven év alatt a rendelkezésére álló eszközökkel erején felül munkálta a haza javát, müvelését. Legfóbb eredményeinek egyike, hogy biztosította az erdélyi részekben a magyarság számára a tudományegyetemet, mellyel ma karöltve halad céljai felé.

Az Egyesület kebelében kialakult öt tár közül, ti. a könyvtár, érem- és régiségtár, állat-, növény- és ásványtár közül a minket leginkább érdeklő éremtárnak bölcsője ott ringott az 1842-i országgyűlésen. Születésében csaknem olyan fontos tényezője volt a létesítendő múzeumnak, mint a gróf 
Kemény-féle könyvtár. Az éremtár alapját ti. gróf Eszterházy László vetette meg azzal, hogy a nevezett országyülésen gazdag és értékes régi pénzgyüjteményét szintén a haza oltárára tette le, a múzeum számára ajánlotta fel. Példáját követték ugyanazon országgyülésen dr. Lészay Dániel és Goró Lajos. Lészay 1000 darabot meghaladó éremgyüjteményét ajánlotta fel, Goró Lajos őrnagy, egyéb tárgyakon kívül, 450 darab római érmet.

A gróf Kemény halálával felszínre került múzeumi kérdés kapcsán és a Mikó által hozott újabb áldozat hatása alatt támadt honfiúi felbuzdulásnak aránylag legtöbb hasznát az éremtár látta. Az Egyesület még nem tekinthetett három éves múltra vissza, mikor az éremtár azzal dicsekedhetett, hogy 18 000-nél több pénzdarabot és pénzjegyet őriz. Amint azonban a politikai láthatár tisztulni kezdett, úgy csappant az érdeklődés a múzeum és ezzel együtt az éremtár iránt is. Istenben boldogult érdemes igazgatója, dr. Finály Henrik, egy pillanatra sem szünt meg munkálni, fáradozni érdekében. Valósággal dédelgette az éremtárat. Hosszú időn át hitte, hogy a társadalom közönyét ellensúlyozza a kormány, hisz az idők megváltoztak a század eleje óta, és másfelől is erre kötelezte az egyetem felállítása alkalmával az Egyesülettel kötött szerződése. Mindhiába aggódott a vezetése alatt álló tárak sorsa miatt. Az Egyesület pénzügyi viszonyai alig biztosították azok fejlődését, a kormány pedig nem teljesítette vállalt kötelezettségét. Anélkül szállott sírba, hogy hő óhaját, az érem- és régiségtár méltó fejlődésének biztosítását elérhette volna.

Az éremtár fejlődése folyamán mutatkozó stagnálás csak akkor szünt meg, mikor alig 9 esztendővel ezelőtt új jövedelmi forrásokat nyitott az állam a tárak számára, és dr. Pósta Béla egyetemi tanár, az érem- és régiségtár jelenlegi igazgatójának ismételt sürgetésére biztosította az állami éremleleteknek megvásárlási jogát. Jóllehet ezek a leletek csak azután küldetnek le, ha előbb már a Magyar Nemzeti Múzeum és a Budapesti Tudomány-Egyetem éremtára élt a kiválogatás jogával, mégis gazdag és főleg olcsó gyarapodási forrásai az éremtárnak.

Ma az éremtár körülbelül 30000 darab érmet számlál. Ebből 6403 darab ókori, 7460 darab hazai és 11828 darab külföldi. Több mint 2000 emlékérem. Ezekhez jön még az Eszterházy-féle gyüjtemény 3779 pénzdarabbal és emlékéremmel. Általános gyüjtemény. Az ókori érmek leggyengébb osztálya a görög érmeké. Legváltozatosabb sorozatokat mutat fel római köztársasági és császárkori pénzekből. Gazdag anyag képviseli középkori érmelésünk emlékeit az ún. múzeumi gyüjteményben, míg Erdély enemü emlékeit az Eszterházy-kollekcióban találhatjuk meg. Ez utóbbi a tárháza az éremtár tulajdonában levő emlékérmeknek is. 
A gyűjteményt annak idején dr. Finály Henrik rendezte. Helyszíni kezelésénél a kartonlapokba mélyített lokulus-rendszert fogadta el, s az így elrendezett gyűjteményről egy könnyen használható, átnézetes lajstromot készített. Ma 12 új szekrény áll rendelkezésre abból a célból, hogy a gyưjtemény azokban leljen új elhelyezést. Az érmek átrakása már meg is történt, sőt a rendezés is meglehetősen előrehaladt. Minthogy azonban a fiókokban rögzített új rendszer nyer ez alkalommal bevezetést, és minden éremről külön cédula készül, a rendezés munkája csak lassan haladhat előre.

Az Erdélyi Múzeum-Egylet múlt évi november hó 23-án ülte fennállásának örömünnepét, székhelyén, Kolozsvárt, egy díszközgyưlés keretében. Az egyetem auláját ez alkalomból színültig megtöltötték a jubiláns Egyesület üdvözlésére siető testvérintézetek, a kormány, az iskolák, különbözó törvényhatóságok és városok képviseletében, az ország legkülönbözőbb pontjairól összesereglett kiküldöttek. Ô Felsége, a király képiseletében gróf Bánffy György főajtónállómester adta meg az engedélyt a gyülés megnyitásához, mire az Egyesület kiváló elnöke, gróf Eszterházy Kálmán megnyitó beszéde során, visszatekintve az Egylet múltjára, egyrészt háláját rótta le a nemzet nagyjai iránt, akik meg\{terem\}tették és felvirágoztatták azt, másrészt pedig lelkes szavakkal ecsetelte az Egylet működésének hatását hazai kultúránk fejlesztésére, tökéletesítésére. Majd a szebbnél szebb, lelkesebbnél lelkesebb üdvözlő beszédek hosszú sora következett. A Magyar Numizmatikai Társulat és a Magyar Heraldikai Társulat nevében dr. Finály Gábor köszöntötte az Egyesületet, mint akit boldogult atyja, dr. Finály Henrik révén közelebbi kötelékek is füznek az Egyesülethez.

Az üdvözlőbeszédek elhangzása után az új adományozók és új tagok névsorát olvasta fel a titkár, ezután dr. Schilling Lajos főtitkár tartotta meg igazán szép, magvas beszédjét az Egyesület múltjából vett tárgykörrel.

Ezután az elnök hálás szívvel köszönte meg a minden oldalról megnyilatkozott érdeklődést, örömmel fejezte ki az Egyesületet ért kitüntető elismerések felett, és szerencsésnek mondotta magát azért, hogy ott lehetett az Egyesület alapításánál, most pedig, 50 év múlva, vezethette annak jubiláris közgyűlését.

Végül, az esőzés miatt, gróf Mikó szobrának megkoszorúzása helyett a teremben pálmák közé felállított életnagyságú olajfestménye elé járultak, s koszorúk lehelyezésével hódoltak a nagy alapító szellemének az Egyesület nevében dr. Lechner Károly alelnök, az egyetem nevében dr. Udránszky László, az egyetem ez idei rektora. 
Az ünnepély egész lefolyása, komoly külszíne, nemes tartalma minden jelenlévőben méltán kelthette azt a jóleső érzést, hogy az Egyesület 50 év alatt azzá lett, amivé alapítói tervezték, a hazai kultúra tényezőjévé. Egy erkölcsileg súlyos, hatalmas intézménnyé fejlődött, mely igaz, nemes munkával szolgálja a nemzet múvelését.

Az EME plakettel örökítette meg 50 éves fennállásának emlékét. A választmány a művész személyének megválasztásánál nemcsak a művészi talentumokat vette tekintetbe, hanem súlyt kívánt helyezni arra is, hogy az erdélyi részek szülötte legyen. Így állapodott meg ifj. Vastagh György személyében, kinek keze alól csak nemrég került ki a budapesti XVI. nemzetközi orvoskongresszus plakettje is. Ifj. Vastagh György jól ismert tehetsége eleve biztosította a feladat művészies megoldását, másrészt pedig mint Kolozsvár szülötte, a kívánalmak második felének is megfelelt. Pár nap alatt bemutatta a választmány előtt a plakettnek viaszba mintázott tervezetét, mely annyira megnyerte a tetszést, hogy a művészt azonnal megbízták a kivitellel is. Így jutott az Egyesület egy művészies plaketthez, mely méltó megörökítője alapítása történetének, 50 éves múljának, és így gyarapodott a magyar éremmetsző művészek alkotása egy jelentős darabbal.

Előlapján, a bal oldali előtérben egy Nemtő áll az oszlopcsarnokos épület sarkán. Bal kezében Viktoriát tart, jobbjával a jobb oldali háttérben emelkedő palotára mutat. Lábával egy hatalmas sárkány nyakára tapos. A plakett bal, hosszanti szélén, az épület falán, kifelé fordított homorú betűkkel IFJ. VASTAGH GY.

Hátlapján, a felső részen babérágakból font koszorú között gróf Kemény József mellképét félig elfödi gróf Mikó Imre mellképe. A koszorú felül nyitott, jobbról és balról széles szalag fonja át.

A jobb oldali szalagon az alulról kiinduló felirat domború betűkkel GR MIKÓ IMRE, a bal oldali szalagon felülről kiinduló felirat, szintén domború betűkkel: GR: KEMÉNY JÓZSEF. A plakett alsó kisebb felét egy album tölti be, melynek csigavonalba szaladó két felső sarkáról egy bojt csüng alá. Az album tábláján domború betűkkel ERDÉLYI MÚZEUM I EGYESÜLET | 1859 - 1909; alsó bal sarkán homorú betűkkel IFJ. V. GY. Az albumot és a babérkoszorút a szalag köti össze.

A Nemtő a haza Nemtője, a sárkány a haza ellensége, az ármány, melyen a nemzet csak úgy vehet diadalmat, ha, a Nemtő útmutatása szerint, felkarolja a múzeumi eszmét, és megvalósítva azt, táplálja a múlt emlékét, és szolgálja általa a nemzet müvelését, a nemzeti összetartást. Az eszme itt már diadalát üli. Ezért nem küzd már a Nemtő a szörnnyel. Egész testsúlyával a jobb lábára nehezedik, bal lábát ellenben térdben könnyedén meghajlítva a sárkány nyakán pihenteti. Félig leövezett vékony drapériája bal csípőjéről aláhullva szabadon hagyja az egész bal oldalt, míg másik 
vége bal karjára van vetve. Az eszme diadala közvetlenebb kifejezést a Nemtő arcvonásaiban, egyéb mozdulataiban és abban a környezetben lel, amelybe a művész helyezte. Jobbjával energikusan mutat a háttérben álló emeletes épületre, a múzeumi eszme képviselőjére. Bal karjával az architektúra alacsony párkányára könyököl, de felemelt kezében Nikét tart már. A múzeum épülete mögött felkelő nap máris szétöntötte sugarait az égboltozaton, míg az épület előtt egy oltár füstje száll a magasba.

A Nemtő figyelmeztetését gróf Kemény József és gróf Mikó Imre értették meg. Az ő áldozatkészségük, fáradozásuk gyümölcse az 50 év előtt megalakult Erdélyi Múzeum-Egyesület, mely most háláját rótta le fennkölt alapítóival szemben.

A minden ízében szépen kidolgozott plakett mintáját a Steiner Ármin és Ferenc ércműáru cég öntötte bronzba Budapesten. Ott redukálták, ott készítették a verőtöveket, és ott verték a plaketteket is. Úgy a bronzmintát, mint a verőtöveket az Erdélyi Nemzeti Múzeum érem- és régiségtára szerezte meg.

Vertek: ENM.

a) két aranyat 60x45 mm nagyságban, egyenként 150 gramm súllyal. ENM.

b) két ezüstöt, hasonló nagyságban, egyenkint $96^{\circ} 2$ gramm súllyal.

c) 500 bronzot hasonló nagyságban, egyenkint $90^{\circ} 6$ gramm súllyal. ENM.

Valamennyi homályosított.

Az aranyak csak annyiban különböznek az ezüst- és bronzpéldányoktól, hogy a hátlapot tekintve, a plakett jobb hosszanti peremén aranyponc van bemélyítve.

Az első veretű arany- és ezüstpéldányokat az Erdélyi Nemzeti Múzeum éremtára őrzi, míg a másik arany ő Felsége számára, az ezüst pedig az Egyesület elnöke számára készült. Bronzpéldányok tíz korona ellenében kaphatók. Az Erdélyi Múzeum-Egyesület, a Magyar Numizmatikai Társulat és a Magyar Éremkedvelők Egyesületének tagjai kedvezményes árban 8 koronáért szerezhetik meg. Akik birtokába akarnak jutni a plakettnek, forduljanak az Egyesület pénztárosához, Lendvay Emil kir tanácsos bankigazgató úrhoz (Kolozsvár, Erdélyi Bank). 
